\title{
IMPROVING ENGLISH VOCABULARIES THROUGH DERIVATIONAL MORPHEME
}

\author{
Evan Afri, Surya Hendra Putra \\ Politeknik Ganesha Medan, Indonesia \\ E-mail: evanafri@gmail.com
}

Received: 2021-09-16

Accepted: 2021-12-01

\begin{abstract}
This research aims to improve students' vocabulary acquisition through the strategy of deriving suffixes. The populations of this study are students from Politeknik Ganesha Medan in second semester. This research was conducted through Applied Classroom Action Research (CAR), born in two cycles (cycle 1 and cycle 2), and each process consisted of four meetings. The vocabulary test results showed that the average improvement score of the pre-test was 34.66, the post-test of period 1 was 93.46 , and the posttest of period 2 was 97.33 . In the first cycle, the nominal comparison rate was $88.83 \%$, the verb nature was $77.46 \%$, the adjective nature was $40.74 \%$, and the adverbial heart was $84.14 \%$. In cycle 2 , the nominal comparison rate was $100 \%$, the verb nature was $95.45 \%$, the adjective nature was $65.84 \%$, and the adverbial nature was $94.91 \%$. The proportion of students who passed Minimal Criterion Mastery in each cycle was $100 \%$, cycle 1 increased by $169.64 \%$, and cycle 2 increased by $180.81 \%$. These indicate that there is a significant improvement of the students' vocabulary mastery through derivational morpheme strategy of the students of Politeknik Ganesha Medan.
\end{abstract}

Keywords: vocabulary, derivational morpheme, derivational suffixes, derivational prefix, Classroom Action Research

\section{Introduction}

Mastering vocabulary plays a vital role in English. It is essential to gain basic English skills (such as listening, speaking, reading, and writing). Thornbury (2002) points out that without grammar, no good sentence could be produced. It is similar to Injeeli (2013), who points out that if language structure forms the backbone of language, vocabulary can provide vital organs and bodies. According to these statements, if students do not have a broad vocabulary, they will not speak or write anything in English. If the student does not have enough vocabulary to express the meaning accurately, the ability to use the structure and function of the grammar will be useless. In addition, one part of vocabulary is to construct each sentence with language. It is correct because the students' English fluency can be seen from their speech and how to use English in a meaningful way.

The most striking attribute of human beings is the ability to use language-studying the nature of language and the way defined as linguistics. The primary way to see the existence of a language is through words. It is almost impossible to learn a language without a language because of communication among people based on observations. 
By learning morphology, students will understand how words are entered into the language, what they are made of, and how to form words by combining prefixes, suffixes, and roots. Therefore, morphology can be a valuable guiding tool for students to develop and use vocabulary creatively. Nijakowska (2010) points out that morphology focuses on how to construct words from parts. Many words can be divided into smaller units-morphemes, constituting the smallest linguistic unit with meaning (for example, unhappy, unlucky, unsatisfied). Some words cannot be further decomposed (for example, car), they are free morphemes because they can exist independently, and bound morphemes (-un, -s, or -ed) are always appended to some other morphemes. Bound morphemes can be divided into derivative morphemes and inflection morphemes in compound words according to their functions. According to the examples, comments are usually added by bound morphemes. This is called attaching. Affixes can reorganize morphemes through morphology to construct new meanings.

Derived affixes can appear in unlimited phrases. Adeniyi (2010) points out that derived morpheme is a kind of bound morpheme, which generates or creates new words by changing parts of speech or forming new words. Jackson and Amvela (2007) points out that once a derivative affix changes the category added to the stem, a derivative word is formed, automatically marking it as a noun, verb, adjective, or adverb. For example, it can be analyzed as follows by adding a suffix to beauty (noun).

$$
\begin{aligned}
& \frac{\text { Beauty }}{\text { Root (noun) }}+\frac{f y}{\text { Suffix }}=\frac{\text { Beautify }}{\text { Verb }} \\
& \frac{\text { Beauty }}{\text { Root (noun) }}+\frac{\text { full }}{\text { Suffix }}=\frac{\text { Beautiful }}{\text { Adjective }} \\
& \frac{\text { Beauty }}{\text { Root (noun) }}+\frac{f u l}{\text { Suffix }}+\frac{\text { ly }}{\text { Suffix }}=\frac{\text { Beautifully }}{\text { Adverb }}
\end{aligned}
$$

Related researches have studied the role of affixes in improving vocabulary. The first research was conducted by (Bhatti, 2016) in the journal entitled "Improving Vocabulary through Affixes at Secondary Level". It was pointed out here that using affix strategies could significantly improve vocabulary. The average score of the students in the post-test is higher than the average score in the pre-test, which was statistically proved. The average score increased from 64.04 in the pre-test to 68.21 in the post-test. Kim (2013), conducted the research entitled "Affixed Vocabulary Acquisition: Learning English Words Based on Prefixes and Suffixes", and pointed out that affix strategies can help students master English vocabulary more quickly.

Teaching vocabulary is not a simple task. Almost everyone realizes that teaching vocabulary will only waste time because the number of languages is unlimited. To deal with this fact, one possible way to expand the speech is to use affixes. Most affixes can be found in the English text. According to the authors' observations at Politeknik Ganesha Medan, it is found that the students have difficulty in learning vocabulary. They make a mistake in interpreting the word's meaning in the sentence because it contains an affix. They rarely realize that the definition will change according to its part of speech. Students have less understanding of word families. For example:

$$
\frac{\text { Clear }}{\text { noun }}><\frac{\text { Clearly }}{\text { Adverb }}=\text { Jelas (False Interpretation) }
$$




$$
\begin{aligned}
& \frac{\text { Informer }}{\text { noun }}><\frac{\text { Inform }}{\text { verb }}><\frac{\text { Informative }}{\text { Adjective }}=\text { Informasi (False Interpretation) } \\
& \frac{\text { Powerless }}{\text { adjective }}><\frac{\text { Powerful }}{\text { adjective }}><\frac{\text { Powerfully }}{\text { adverb }}=\text { Kuat (False Interpretation) }
\end{aligned}
$$

In addition, some students say that they find it challenging to memorize vocabulary; only a limited number remains. The traditional method is usually to find the meaning in the dictionary by looking up tricky words to remember the new words they have heard or read in English textbooks. It makes students bored and unmotivated by English subjects. If they can use affixes as sub-parts of terms, they can get the number of new words and their meanings because they can easily connect words by determining parts of speech.

\section{Literature Review}

\subsection{Vocabulary}

Vocabulary is related to the meaning of words. Daller (2016) points out that vocabulary knowledge is considered to include understanding of form, meaning, and use. Nation (2001) points out that the word part is a pervasive and essential aspect of English vocabulary. $\mathrm{Oz}$ (2014) points out that when discussing words, sometimes an important distinction is made between two types of words: content words and function words. Examples of content words include nouns, verbs, adjectives, and adverbs. They are also called open-ended or openended words because we can often add new words to these words. Verspoor \& Sauter (2000) point out that nouns, verbs, adjectives, and adverbs are very open categories because new members join almost every day. According to these theories, nouns, verbs, adjectives, and adverbs have meanings, forming a new vocabulary.

The architectural vocabulary is inseparable from affixes or morphemes. One way to influence vocabulary is to paste. Cain (2010) points out that vocabulary is related to our understanding of word meaning, and morphology is connected to our understanding of word structure, especially morphemes. This is the smallest unit of meaning in a word. Therefore, both involve the understanding of words.

\subsection{Vocabulary Acquisition}

Peukert (2015) states that in second language acquisition, the knowledge of derived language forms and the combination of affixes and affixes in second language acquisition positively impacts learners' acceptance and productive vocabulary.

Word formation involves many processes that can create new words and expand the vocabulary of the language. Lieber \& Štekauer (2014) point out that most English-derived affixes are acquired after children go to elementary school. Some are only obtained when children obtain other sources of information (such as danger) other than speeches on the relationship between another pair of affixes. Time to be mastered. -Dangerous, librarian or volcano. When a child gets what, it also depends on which language they are learning. In some languages, the derivation is the primary condition for constructing new words.

\subsection{Morphology}

Morphology is the branch of linguistics on how words in a language are attached. It is connected with the systematic form and meaning correspondence in the vocabulary. Haspelmath \& Sims (2010) state that morphology is a systematic and covariant study of the 
form and meaning of words. Vadasy \& Nelson (2012) say that morphological analysis also makes an essential contribution to the growth of students' vocabulary. Students can be taught to decompose an unfamiliar word into multiple parts, identify the meaning of each part, and then put the parts back together to get the meaning of the word. Morphology is the ability to understand how morphemes are formed through morphemes. Dechaine (2012) states that the goal of morphology is to find the smallest unit of meaning-morphemes and understand how these units are combined to form words. Hair (2008) points out that morphology can obtain information about the meaning of new words by looking at prefixes, roots, and suffixes.

\section{a. Morpheme}

Morphemes are parts of morphology. They increase vocabulary knowledge. Oakhil (2015) points out that one of the sources of this impressive increase in vocabulary knowledge is the acquisition of the constituent units of word meaning (morphemes). Traxler (2012) points out that a single word is composed of one or more morphemes. Plag (2002) points out that the essential feature of traditional morphemes is that they are considered units of form and meaning. Lems, et al. (2010: 94) point out that affixes are morphemes, but they are not words and cannot exist independently. Denham \& Lobeck (2010) points out that morphemes belong to different categories like words. Morphemes are restricted or unrestricted. The terms drink, cat, and butter are all free morphemes. They are monomorphemic and can exist alone as words. The Bound morphemes themselves have different types: -ize is a suffix, and un- is a prefix. Suffixes and prefixes are affixes, more general titles of morphemes; these affixes are attached to other morphemes or words through a process called affixes.

\section{b. Root}

Using roots to unlock word meanings will do more than expand students' vocabularies. They say that when we teach language based on roots rather than word lists, we encourage our students to search for a word's meaning from the meaning of its root. The root consists of an only noun, verb, adjective, and adverb. These belong to the open classes or contents word because they hold the meaning itself. Lee (2015) states that essential parts of speech classes include nouns, verbs, adjectives, and adverbs. These words belong to open courses because they can be extended using word-formation. Adams (2014) states that the productive formation of new words in English is usually word-based; that is, the base of a regularly formed new complex word must be able to occur also as an independent member of a significant word-class - noun, adjective, or verb. For example, defend defensive, curious, curiosity.

\subsection{Derivational Morpheme}

Fromkin, Robert, \& Nina (2014) explain that when a derivational morphemes is added to a base, it adds meaning. It means that derivational morpheme creates new word and new meaning.

According to Critten (2014) derivational morphemes may occur at the beginning (prefixes) or end of a word (suffixes) and produce semantic changes by transforming the grammatical form of a word." It means derivational morpheme is the affixes that change the word meaning. 
Based on the experts' explanation above, the author concludes that the derivational morphemes are affixes. It can change the meaning of basic words and create new words. The meaning can be changed to the opposite meaning, from positive to negative. Like morphemes Dis- on the word Disagree. The basic word is "agree", which has the meaning of approving something. However, when Dis- is added, the meaning becomes the opposite or not approved.

In general, Fromkin et al., (2014: 45) categorizes derivational morphemes into

\begin{tabular}{|c|c|c|}
\hline Noun To Adjective & Verb to Noun & Adjective to Adverb \\
\hline boy + -ish & acquitt + -al & exact +- ly \\
\hline virtu + -ous & clear + -ance & \\
\hline elizabeth + -an & accus + -ation & \\
\hline pictur + -esque & sing + -er & \\
\hline affection + -atc & conform + -ist & \\
\hline health + -ful & predict + -ion & \\
\hline \multicolumn{3}{|l|}{ alcohol + -ic } \\
\hline Noun to Verb & Adjective to Noun & Verb to Adjective \\
\hline moral + -ize & tall + -ness & read + -able \\
\hline vaccin + -ate & specific + -ity & creat + -ive \\
\hline hast + en & feudal + -ism & migrat + -ory \\
\hline $\mathrm{im}+$ Prison & free + -dom & $\operatorname{run}(n)+-y$ \\
\hline \multicolumn{3}{|l|}{ be + friend } \\
\hline \multicolumn{3}{|l|}{ en-+ joy } \\
\hline \multicolumn{3}{|l|}{ in- + habit } \\
\hline \multicolumn{3}{|l|}{ Adjective to Verb } \\
\hline \multicolumn{3}{|l|}{ en + large } \\
\hline \multicolumn{3}{|l|}{ en + dear } \\
\hline en + rich & & \\
\hline
\end{tabular}

Some derivational affixes do not cause a change in grammatical class

\begin{tabular}{|lll|}
\hline Noun to Noun & Verb to Noun & Adjective to adjective \\
\hline friend + -ship & un- + do & pink + -ish \\
\hline human + -ity & re- + cover & red + -like \\
\hline king + -dom & dis- + believe & a- + moral \\
\hline New Jersey + -ite & auto + destruct & il- + legal \\
\hline vicar + -age & & in- + accurate \\
\hline Paul + -Ine & & un- + happy \\
\hline America + -n & & semi- + annual \\
\hline libr(ary) + -arian & & dis- + agreeable \\
\hline mono- + theism & & sub- + minimal
\end{tabular}




\begin{tabular}{|l|}
\hline dis + advantage \\
\hline ex- + wife \\
\hline auto + Biography \\
\hline un- + employment \\
\hline
\end{tabular}

It means derivational morpheme divided into two types in familiar groups. The first is derivational morphemes that change the part of speech. The second is that do not modify the part of speech. After being added by derivational morpheme, the class word of the base word does not change.

\subsubsection{Derivational Suffixes}

Affix is the process of adding morphemes to the root to form new words. Adebileje (2013) points out that the process of creating new comments by adding morphemes is called affixes. The derivation allows us to add new lexical items to the open word category of nouns, adjectives, verbs, and adverbs. These are classes that contain so-called content words. Derived suffixes are the most commonly used affixes to change parts of speech and word meaning. Huddleston \& Pullum, (2005) point out that most affixes that change categories are suffixes. Plag (2002) points out that English suffixes can be divided into the following categories: nouns, speech, adjectives and adverbials.

\section{a. Nominal Suffixes}

Plag (2002) states that nominal suffixes are often employed to derive abstract nouns from verbs, adjectives and nouns. For example:

$\begin{array}{ll}\text { (-age) } & : \text { result of an action (marriage, advantage), a collective entity } \\ \text { (-al) } & \text { (acreage, voltage), to state location (orphanage) } \\ \text { (-ance), (-ence) } & : \text { act or condition of (performance, importance, evidence) } \\ \text { (-ancy), (-ency) } & : \text { action(expectancy, dependency) } \\ \text { (-ant) } & : \text { a thing or a being (assistant, accountant, participant) } \\ \text { (-cy) (-ce) } & : \text { state or quality (agency, emergence) } \\ \text { (-dom) } & : \text { collective entity (professordom, studentdom) } \\ \text { (-ee) } & : \text { one who (employee) } \\ \text { (-eer) } & : \text { person who deals in (auctioneer, budgeter) } \\ \text { (-er) } & : \text { one who, that which (manager, leader, officer, speaker) } \\ \text { (-ry) } & : \text { place for, collection of (anniversary, library, summary) } \\ \text { (-ness) } & : \text { condition or state of (bussiness, awareness, happiness) } \\ \text { (-ful) } & : \text { measure partitive nouns (cupful, handful) } \\ \text { (-hood) } & : \text { condition of being (motherhood, neighbourhood, boyhood) } \\ \text { (-ian) } & : \text { one who (musician, comedian, vegetarian, physician, civilian) } \\ \text { (-ion) } & : \text { act or condition (information, population, competition) } \\ \text { (-ism) } & : \text { practice, belief, attitude (metabolism, modernism, journalism) } \\ \text { (-ist) } & : \text { one who (economist, guitarist, dentist, receptionist, scientist) } \\ \text { (-ity) } & : \text { state or quality of (opportunity, possibility, majority) } \\ \text { (-ment) } & : \text { state or act of (department, equipment, employment) } \\ \text { (-ship) } & : \text { art or skill of, condition, rank, group of (fellowship, membership, } \\ & \text { friendship, championship, ownership) }\end{array}$




\section{b. Verbal Suffixes}

Plag (2002) states that there are four suffixes which derive verbs from other categories (mostly adjectives and nouns), namely -ate, -en, -ify and -ize.

(-ate) : to make (communicate, appreciate, anticipate, estimate, translate)

(-en) : : make more (blacken, broaden)

(-ify) : locative, ornative, causative (trustify, humidify)

(-ize) : : to make (criticize, summarize, mobilize, apologize, criticize)

\section{c. Adjectival Suffixes}

Plag (2002) states that the adjectival suffixes of English can be subdivided into two major groups. A large proportion of derived adjectives are relational adjectives, whose role is simply to relate the noun the adjective qualifies to the base word of the derived adjective. For example, algebraic mind means 'a mind having to do with algebra, referring to algebra, characterized by algebra', colonial officer means 'officer having to do with the colonies', and so on. On the other hand, there is a large group of derived adjectives that express more specific concepts, and which are often called qualitative adjectives. Sometimes, relational adjectives can adopt qualitative meanings, as can be seen with the derivative grammatical, which has a relational meaning 'having to do with grammar' in the sentence she is a grammatical genius, but which also has a qualitative sense 'conforming to the rules of grammar', as in 'This is a grammatical sentence'. Note that relational adjectives usually occur only in attributive position, i.e. as prenominal modifiers (as in a lexical problem). If we find them in predicative position in a clause (as in This sentence is grammatical), they usually have adopted a qualitative sense.

$\begin{array}{ll}\text { (-able) } & \text { : capable of being (fashionable, agreeable) } \\ \text { (-al) } & \text { : result of an action (federal, institutional) } \\ \text { (-ary) } & \text { : having a tendency or purpose (complementary, evolutionary) } \\ \text { (-ed) } & \text { : having, being provided with (broad-minded, wooded) } \\ \text { (-esque) } & \text { : in the manner or style of (picturesque, Kafkaesque) } \\ \text { (-ful) } & \text { : having, being characterized by (beautiful, insightful) } \\ \text { (-ic) } & \text { : related to art or science (economical, historical) } \\ \text { (-ish) } & \text { : convey the concept of somewhat (clearish, freeish) } \\ \text { (-ive) } & \text { : having, being(connective, explosive) } \\ \text { (-less) } & \text { : without (hopeless, speechless) } \\ \text { (-ly) } & \text { : in the manner of, like an (brotherly, daughterly) } \\ \text { (-ous) } & \text { : processing (curious, barbarous) }\end{array}$

\section{d. Adverbial Suffixes}

Plag (2002: 122) states that suffix -ly is appended to nouns and adjectives. With base nouns denoting persons, -ly usually conveys the notion of in the manner of $X$ or like an $X$, as in brotherly, daughterly, fatherly, womanly. Other common types of derivative have bases denoting temporal concepts (e.g. half-hourly, daily, monthly) or directions (easterly, southwesterly). The adjective forms adverb from adjectives. For example: -ly (usually, busily, proudly, loudly, gratefully),-wise (crosswise).

\subsubsection{Derivational Prefixes}

Quirk (1973) states that prefix adds before the base form, with or without change of word class. There are many kinds of the prefix in English: dis-, under-, un-, up, in-, etc. In 
addition, The derivation is also subdivided into class-changing and class-maintaining. Category change means that the influence of derivation can change the word category, and the meaning of the base word can also be changed. On the other hand, category retention means that the derivation process only changes the grammatical morphemes but does not change the word category and meaning.

\subsubsection{Verbal Prefix}

The verb prefix is to add the prefix to the position of the word. The generated word is a verb. For example, adding en- to'joy' will get'enjoy', which is a verb.

(con-) : together, with (control, contract, continue, consider, conduct, convey)

(Im-) : not (improve, Import, imply, imagine, impress, immune, impute)

(en-) : enjoy, encourage, enable, encounter, entertain, enhance, enrich)

(dis-) : from, reduce, or opposite (disagree, disregard, disrespect, disbelieve)

(trans-) : across, over, through (translate, transform, transpose, transmit)

\subsubsection{Adjectival Prefix}

The Adjective prefix is to add the prefix to the position of the word. The generated word is an Adjective. For example, adding un- to' impressed ' will get' unimpressed ', which is an Adjective.

(dia-) : across (diabetic, diagonal, diagrammatic, diagenetic, diabolical)

(mono-) : one, single (monotonous, monotonic, monolingual, monotheistic)

(uni-) : one, single (unimpressed, unidirectional, uninhibited, unimpeachable)

(bene-) : good, well (beneficial, benevolent, benedictory, benefic, beneship )

(sub-) : : under, beneath (substantial, subordinate, suburban, subjective,)

(inter-) : among, between (international, interim, interrogation, interminable)

(intra-) : within (intravenous, intractable, intraperitoneal, intracellular)

(non-) : completely not (non-existent, non-aligned, non-governmental)

(ill-) $\quad$ : not (illiterate, illusory, illegitimate, ill-informed, ill-equipped)

(ir-) : not (irritable, irrevocable, irreconcilable, irredeemable, ironical)

(counter-) : against, opposite ( counterfactual, counter-productive, counterfeit)

(therm-) : heat, warm (thermionic, thermographic, thermoelastic, thermostatic)

(auto-) : self (authoritative, autobiographical, authoritarian, automotive)

(Hom-) : same, alike (homogeneous, homoeopathic, homologous, homophobic)

(hydr-) : : water(hydroelectric, hydroxy, hydrographic, hydrodynamic)

(macro-) : large(macroeconomic, macrocosmic, macronuclear, macroangiopathic)

(phot-) : light (photochemical, photogenic, photovoltaic, photosensitive)

(pan-) : all, whole (pancreatic, pandemic, pantisocracy, pancreaticobiliary)

(zoo-) : animal (zoogeographical, zoomorphic, zoocidal, zoogamous)

(chron-) : time (chronomantic, chronometrical, chronologic, chronemic)

(mort-) : to die (mortal, mortallest, mortarlike, mortgageable, mortuary)

\subsubsection{Noun Prefix}

A noun prefix is where a prefix is added to a word, and the resulting word is a noun, for example adding mis- to 'information' gives you 'misinformation', which is a noun.

(de-) : opposite (development, department, decision, description, decline)

(dis-) : from, reduce, opposite (disease, distribution, discretion, discourse)

(trans-) : across, over, through (transition, translation, transportation, transom) 


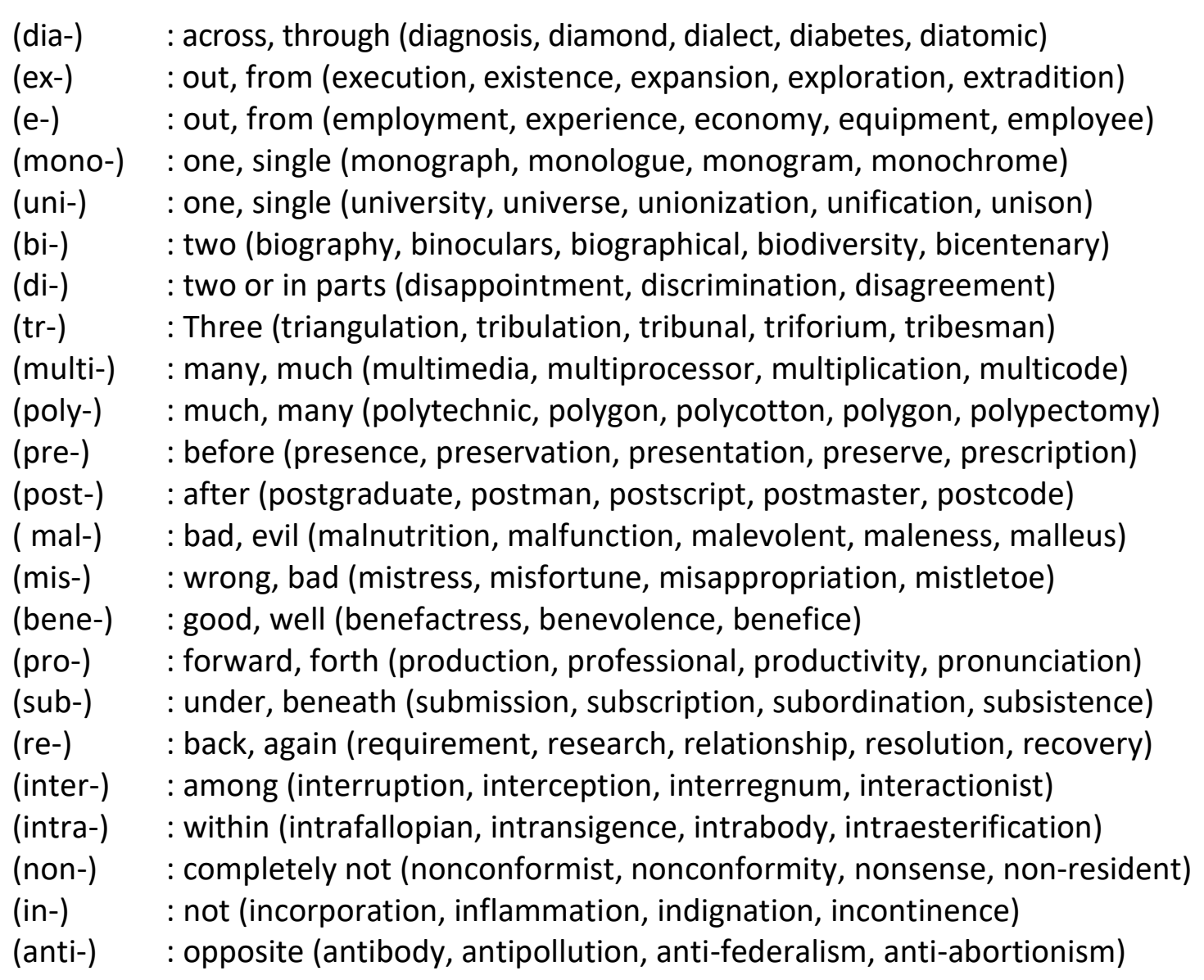

\subsubsection{Adverbial Prefix}

The Adverbial prefix is to add the prefix to the position of the word. The generated word is an Adverbial. For example, adding un- to' impressed ' will get' unimpressed ', which is an Adjective.

(pre-) : before (previously, predominantly, prematurely, predictably)

(en-) : to cause to be (enthusiastically, endoscopically, enigmatically)

\section{Research Method}

\subsection{Research Design}

To achieve this research's goal to improve student's vocabulary mastery level by using affixation strategies, the design of this research adopts the form of "Classroom Action Research" (CAR). The action research is research conducted by teachers of the course to solve problems or improve teaching. Teachers in the classroom conduct action research according to their situation. Teachers determine the issues or areas they wish to improve based on the theories or experiences, or assumptions they believe to be intervention. They documented the interventions and their results. If the impact is positive, it may lead to information dissemination. If not, you can check the cycle.

Classroom action research includes four phases of a cycle: planning, action, observation, and reflection. There are four steps of the classroom action research model here. 


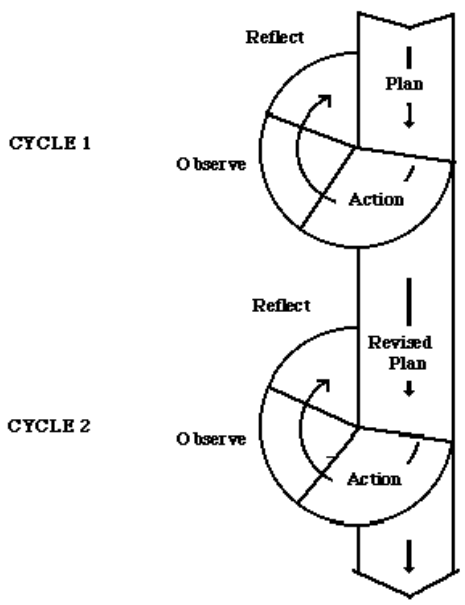

Figure 1. Cyclical Classroom Action Research (CAR) based on Kemmis and McTaggrat in (Burns, 2010)

\section{Results and Discussion}

This chapter describes the data collected from operations. The data consist of the period I and period II. The test is to understand the improvement of students' vocabulary mastery after learning the affix strategy. Quantitative data take the form of a vocabulary test. The following is an analysis of quantitative data:

\section{a. Analysis of Pre-test}

$$
\begin{aligned}
& M=\frac{\sum \mathrm{x}}{N} \times 100 \%= \\
& \mathrm{M}=\frac{1040}{30} \times 100 \%=34.66 \%
\end{aligned}
$$

Based on the pre-test result, all of the students cannot identify nominal, verbal, adjectival, and adverbial. No student passes Minimal Criterion Mastery, whose value is 70 (seventy).

\section{b. Analysis of Cycle 1}

1. Total percentage of Nominal:

$\frac{\text { The students' } \text { maximum score of nominal }}{\text { Total of nominal }} \times 100 \%=\frac{182}{206} \times 100 \%=88.83 \%$

2. Total percentage of verbal

$\frac{\text { The students' maximum score of verbal }}{\text { Total of verbal }} \times 100 \%=\frac{110}{142} \times 100 \%=77.46 \%$

3. Total percentage of Adjectival

$\frac{\text { The students' maximum score of adjectival }}{\text { Total of adjectival }} \times 100 \%=\frac{110}{270} \times 100 \%=40.74 \%$

4. Total percentage of Adverbial

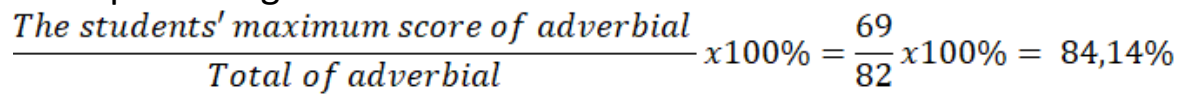




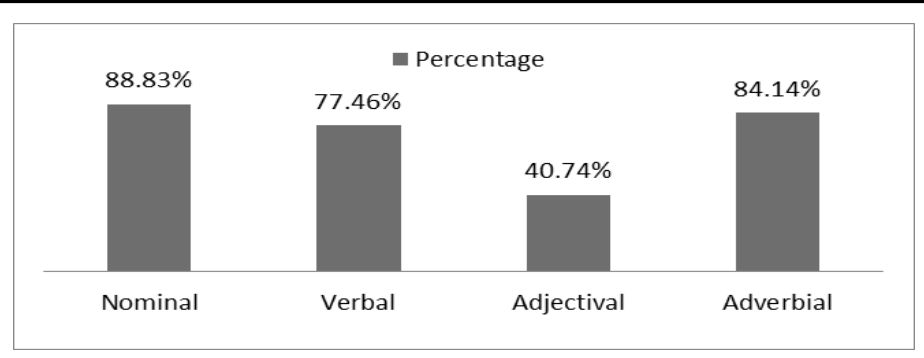

Figure 2. The Result of Students' Affixation in Cycle 1

The mean score in cycle 1:

$$
M=\frac{\sum \mathrm{x}}{N}=\frac{2804}{30}=93.46
$$

The class percentage who passes Minimal Criterion Mastery whose value is 70 (seventy) is calculated as follow:

$$
\begin{aligned}
& P=\frac{\mathrm{R}}{T} \times 100 \% \\
& \mathrm{P}=\frac{30}{30} \times 100 \%=100 \%
\end{aligned}
$$

The first round of students adding words shows that the percentage of students' nominal ability comparison is $88.83 \%$, students' verbal ability is $77.46 \%$, students' adjective ability is $40.74 \%$, and students' ability comparison is $84.14 \%$ in adverbials. The highest proportion of students is nouns (88.83\%), and the lowest proportion of students is adjectives (40.74\%). This indicates that the student has difficulty with adjectives in the first cycle score. According to the results of the first cycle, most students still have adjective problems. The author continues to cycle 2 to improve students' ability of adjectives.

According to calculations, the average score of the pre-test is 34.66 , and the average score of period 1 is $93.46 \%$ (pre-test<period $1=34.66<93.46$ ). The results showed that the scores of vocabulary mastery were improved before and after the action. The class percentage is $100 \%$, which means that all students (30 students) have passed the minimum standard of mastery, which has a value of 70 (seventy students).

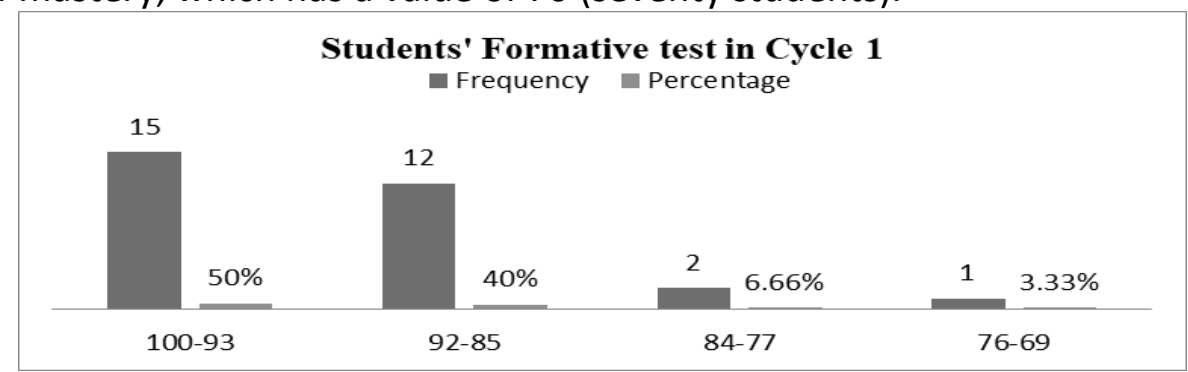

Figure 3. The Result of Students' Formative test

The improvement from pre-test to cycle 1:

$$
\begin{aligned}
& \mathrm{P}=\frac{y 1-y}{y} \times 100 \% \\
& \mathrm{P}=\frac{93.46-34.66}{34.66} \times 100 \%=169.64 \%
\end{aligned}
$$

After calculation, the authors conclude a significant difference between the forecast and the first cycle; that is, the students' performance in the first cycle is higher than in the previous test. This previous test shows that implementing affix strategies can improve students' vocabulary mastery. 


\section{c. Analysis of Cycle 2}

1. Total percentage of Nominal:

$\frac{\text { The students' maximum score of nominal }}{\text { Total of nominal }} \times 100 \%=\frac{120}{120} \times 100 \%=100 \%$

2. Total percentage of verbal

$\frac{\text { The students' maximum score of verbal }}{\text { Total of verbal }} \times 100 \%=\frac{88}{84} \times 100 \%=95.45 \%$

3. Total percentage of Adjectival

$\frac{\text { The students' maximum score of adjectival }}{\text { Total of adjectival }} \times 100 \%=\frac{266}{404} \times 100 \%=65.84 \%$

4. Total percentage of Adverbial

$\frac{\text { The students' maximum score of adverbial }}{\text { Total of adverbial }} \times 100 \%=\frac{112}{118} \times 100 \%=94,91 \%$

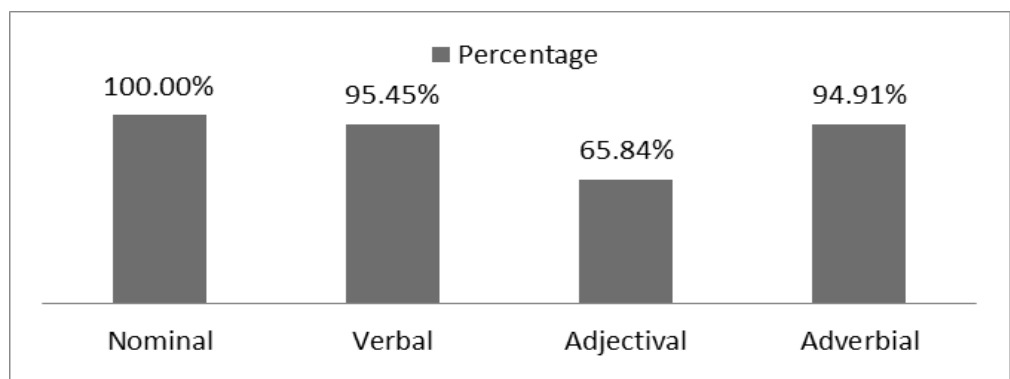

Figure 4. The Result of Students' Affixation in Cycle 2

The mean score of post-test in cycle 2 :

$$
M=\frac{\sum \mathrm{X}}{N}=\frac{2920}{30}=97.33
$$

The class percentage that passes Minimal Criterion Mastery whose value is 70 (seventy) is calculated as follow:

$$
\begin{aligned}
& P=\frac{\mathrm{R}}{T} \times 100 \% \\
& \mathrm{P}=\frac{30}{30} \times 100 \%=100 \%
\end{aligned}
$$

The result of adding words to students in Cycle 2 shows that the percentage of students' nominal ability comparison is $100 \%$, students' verbal ability is $95.45 \%$, students' adjective ability is $65.84 \%$, and students' ability comparison is $94.91 \%$ in adverbials. The highest percentage of students in nominal $(100 \%)$, and the lowest students are adjectives (65.84). According to the post-test results, students' progress in the second cycle increased from $40.74 \%$ in the first cycle to $65.84 \%$ in the second cycle, indicating that the previous review plan has been improved-cycle 1 , especially the ability of students to learn adjectives.

According to calculations, the average score of the pre-test is 34.66 , and the average score of the post-test is 97.33 (pre-test<post-test $=34.66<97.33 \%$. This shows that vocabulary mastery improves the scores before and after the action. The students' vocabulary mastery score increases in cycle 2 . The class percentage is $100 \%$, which means that all students ( 30 students) have passed the minimum standard of mastery, which has a value of 70 (seventy). 


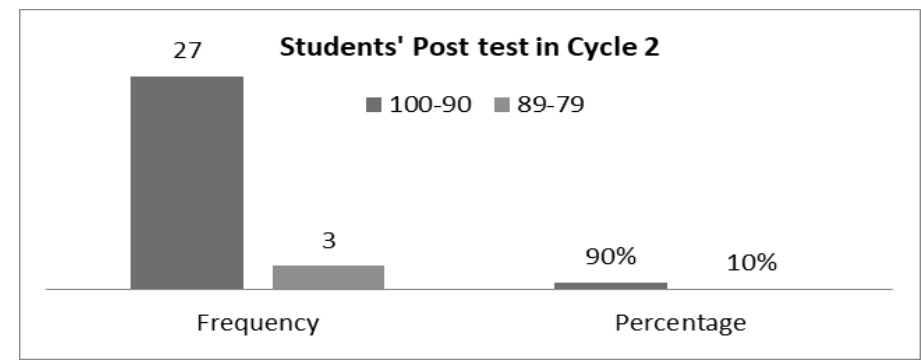

Figure 5. The Result of Students' Post-test of Class IX-1

The improvement from pre-test to post-test:

$$
\begin{aligned}
\mathrm{P} & =\frac{y 2-y}{y} \times 100 \% \\
\mathrm{P} & =\frac{97.33-34.66}{34,66} \times 100 \%=180.81 \%
\end{aligned}
$$

Through calculation, the authors conclude that there is a significant difference between the pre-test and the post-test; that is, the students' post-test scores are higher than the pre-test. This shows that implementing affix strategies can improve students' vocabulary mastery. The following table compares the improvement of students' vocabulary mastery in the pre-test, formative test cycle 1 , and post-test cycle 2.

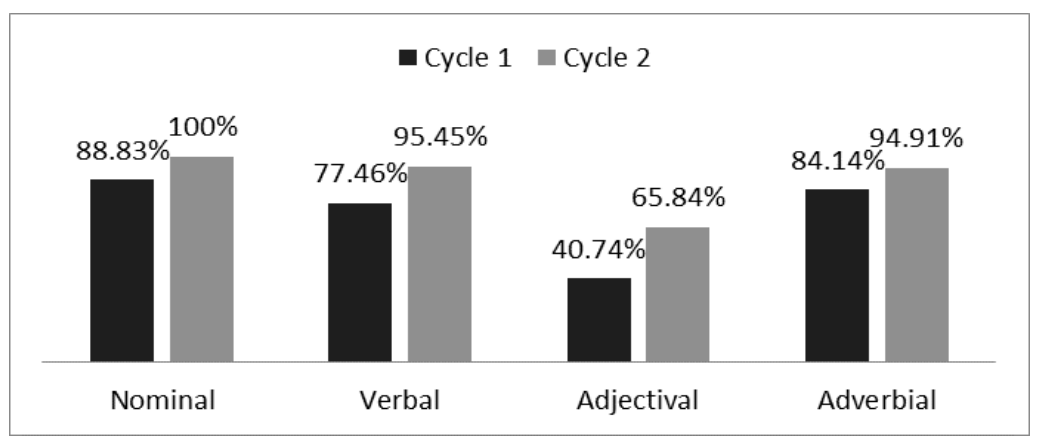

Figure 6. The Comparison of Students' Affixation in Cycle 1 and Cycle

Based on the data analysis, the research results are as follows: First, the results of each test are described as follows: In the pre-cycle, the average pre-test score of IX-1 is 34.66 , which is relatively low. Knowing that vocabulary mastery is an essential part of language, so this problem is solved immediately. In the first cycle, the average score was 93.46. The average score for period 1 is much higher than the predicted average score (93.46> 34.66). All students (30 students) have passed the minimum standard of mastery, 70 (seventy students). In the student comparison, nominalness accounted for $88.83 \%$, oral accounted for $77.46 \%$, adjectives accounted for $40.74 \%$, and adverbials accounted for $84.14 \%$. The highest proportion of students in nominal (88.83\%), and the lowest proportion of students is adjectives (40.74\%). According to the result of affixes, students have difficulty in adjectives. The improvement of the student pre-test to the first-cycle student formative test is $169.64 \%$. It shows that there is a significant improvement from the pre-test to formative test in cycle 1. 
In the second cycle, the average score is 97.33 . The average score after the second cycle was higher than the average score before (97.33\%> 34.66\%). All students (30 students) passed the minimum standard of proficiency, which has a value of 70 (seventy students). When comparing the proportion of students, nouns are $100 \%$, oral is $95.45 \%$, adjectives are $65.84 \%$, and adverbs are $94.91 \%$. The highest proportion of students is nouns (100\%), and the lowest proportion of students is adjectives $(65.84 \%)$. The student's adjective scores increased from $40.74 \%$ in the first cycle to $65.84 \%$ in the second cycle, indicating that the modification plan for the supplementary materials in the first cycle is effective. The improvement of the student pre-test to the second-cycle post-test is $180.81 \%$. It shows that cycle two can be significantly improved over cycle 1.

According to the analysis of research data, in the 2017/2018 school year, the affix strategy effectively improves the vocabulary mastery of students in Politeknik Ganesha Medan.

\section{Conclusion}

Based on the score, which is chosen as the subject of study, the score in the pretest is 34.66. It is in a low category because Minimal Criterion Mastery is 70. The students also cannot identify nominal, verbal, adjectival, and adverbial. Then the writer conducts cycle 1 , and the mean score of the pre-test is improved to 93.46 in cycle 1 . In cycle 1 , the comparison percentage of nominal is $88.83 \%$, verbal is $77.46 \%$, adjectival is $40.74 \%$, and adverbial is $84.14 \%$. The students' highest rate is insignificant ( $88.83 \%)$, and the students' lowest percentage is adjectival (40.74\%). Furthermore, forgetting the better mean score and increasing the students' ability in adjectival, cycle two is conducted, and the mean score is increased to 97.33. In cycle 2, the comparison percentage of nominal is $100 \%$, verbal is $95.45 \%$, adjectival is $65.84 \%$, and adverbial is $94.91 \%$. The highest proportion of students is nouns $(100 \%)$, and the lowest is adjectives (65.84\%). The adjective score increased from $40.74 \%$ in the first cycle to $65.84 \%$ in the second cycle, indicating that the revised supplementary material program for the first cycle is effective. All students have passed the minimum standard of proficiency, which is 70 (seventy).

\section{Acknowledgements}

a) Polytechnic of Ganesha Medan

b) DPRM and Ministry of Education and Culture of the Republic of Indonesia who have supported the implementation of this research.

c) Researchers' family and friends

\section{References}

Adams, V. (2014). Complex Words in English. New York: Routledge Taylor and Francis Group.

Adebileje, A. (2013). A Comparative Description of Affixation Processes in English and Yoruba for ESL Pedagogy. International Journal of Theory and Practice in Language Studies, 1756-1763.

Adeniyi, et. al. (2010). English Morphology. Nigeria: National Open University of Nigeria. 
Bauer, L. (1983). English Word-Formation. Cambridge: Cambridge University Press.

Bhatti, M. S. (2016). Improving Vocabulary through Affixes at Secondary Leve. IJASOSInternational E-Journal of Advances in Social Sciences, 728-732.

Burns, A. (2010). Doing Action Research in English Language Teaching. New York: Routledge Taylor and Francis Group.

Cain, K. (2010). Reading Development and Difficulties. BPS Blackwell: Great Britain.

Critten, Sarah., Vincent Connelly., Julie E. Dockrell., and Kisty Walter. (2014). Inflectional and derivational morphological. Spelling abilities of children with Specific Language Impairment. Vol 4. Retrieved from https://doi.org/10.3389/fpsyg.2014.00948 (2018-05-02).

Daller, et. al. (2016). Language Dominance in Bilinguals: Issues of Measurement and Operationalization. Cambridge: Cambridge University.

Dechaine, et. al. (2012). Linguistics for Dummies. Ontario: John Wiley and Sons Canada.

Denham, K., \& Lobeck, A. (2010). Linguistics for Everyone. Boston: Wadsworth Cengage Learning.

Fromkin, V., Robert, R., \& Nina, H. (2014). An Introduction to Language. New York: Michael Rosenberg.

Hair, L. M. W. (2008). Addressing Word Poverty and Comprehension through Text Talk Direct Instruction Method. Baltimore MD: Paul Brokes Publishing Company.

Huddleston, R., \& Pullum, G.K. (2005). A Students' Introduction to English Grammar. Cambridge: Cambridge University.

Haspelmath, M., \& Sims , A. D. (2010). Understanding Morphology. London: Hodder Education.

Injeeli, P. (2013). Minds Your Words: Master the Art of Learning and Teaching Vocabulary. Singapore: Trafford.

Jackson, H., \& Amvela B. (2007). Words, Meaning, and Vocabulary: An Introduction to Modern English Lexicology. London: Continuum. Katamba, F. (2005). English Words. London: Taylor and Francis e-Library.

Kim, C. (2013). Vocabulary Acquisition with Affixation: Learning English Words based on Prefixes and Suffixes. International Journal of Second Language Studies. 31(2), 43-80.

Lee, et. al. (2015). An Introduction to Korean Linguistics. New York: Routledge Taylor and Francis Group.

Lems, et. al. (2010). Teaching Reading to English Language Learners. New York: The Guilford.

Lieber, R., \& Štekauer , P. (2014). The Oxford Handbook of Derivational Morphology. Oxford: Oxford University.

Nation, I. (2001). Learning Vocabulary in Another Language. Cambridge: Cambridge University.

Nijakowska, J. (2010). Dyslexia in the Foreign Language Classroom. London: Short Run.

Oakhill, et. al. 2015. Understanding and Teaching Reading Comprehension: A Handbook. Routledge: Taylor and Francis Group.

Oz, H. (2014). Morphology and Implications for English Language Teaching: Linguistics for English Language Teaching Studies. Ankara: Ani Publishing. 
Peukert, H. (2015). Transfer Effects in Multilingual Language Development. Amsterdam: Benjamins Publishing.

Plag, I. (2002). Word Formation in English. Cambridge: Cambridge University. Quirk, R. (1973). A University Grammar of English. London: Longman Group Ltd. Thornbury, S. (2002). How to Teach Vocabulary. London: Pearson Education Limited. Traxler, M. J. (2012). Introduction to Psycholinguistics: Understanding Language Science. Malden: Wiley Blackwell.

Vadasy, P. F., \& Nelson, J. R. (2012). Vocabulary Instruction for Struggling Students. London: Guilford.

Verspoor, M., \& Sauter, K. (2000). English Sentence Analysis: An Introductory Course. Amsterdam: John Benjamins Publishing Company. 